\title{
Nursing students' health profile: epidemiological diagnosis based on the PRECEDE-PROCEED model
}

Perfil de saúde dos estudantes de enfermagem: diagnóstico epidemiológico a partir do modelo PRECEDE-PROCEED

Perfil de salud de los estudiantes de enfermería: diagnóstico epidemiológico a partir del modelo PRECEDE-PROCEED

Fernanda Maria Príncipe Bastos Ferreira*; Liliana Andreia Neves da Mota**; Irma da Silva Brito ${ }^{* * *}$; Margarida Reis Santos****

\begin{abstract}
Background: The identification of nursing students' health profile is essential to develop healthy academic communities. Objective: To analyze students' health profile with a view to designing intervention strategies based on the PRECEDE-PROCEED model.

Methodology: Quantitative study. Data were collected using the Portuguese version of the following questionnaires: the Fantastic Lifestyle Assessment, the Stunkard Figure Rating Scale, the Rosenberg Self-esteem Scale, and the Psychological General Well-Being Index. A total of 224 undergraduate and postgraduate nursing students participated in this study.

Results: Students' overall lifestyle is very good. However, lower scores were found in the Physical activity/Affiliation, changes in Nutrition, altered sleep and low stress management ability, Work/Personality type, and Insight, which suggests that students are less optimistic and positive about life.

Conclusion: The intervention plan includes support, education, protection, and prevention should be adapted to students' individual needs and integrated into the curricula.
\end{abstract}

Keywords: health profile; life style; students, nursing

\section{Resumo}

Enquadramento: A definição do perfil de saúde dos estudantes de enfermagem é fundamental no desenvolvimento de comunidades académicas salutogénicas.

Objetivo: Analisar o perfil de saúde dos estudantes, tendo em vista a definição de estratégias de intervenção através do modelo PRECEDE-PROCEED.

Metodologia: Estudo quantitativo. A recolha de dados foi efetuada com recurso à versão portuguesa dos questionários: Estilo de Vida Fantástico, Escala de Autoimagem de Stunkard, Escala de Autoestima de Rosenberg e Questionário do Bem-estar Psicológico. Participaram neste estudo 224 estudantes dos cursos de licenciatura e pós licenciatura de especialização em enfermagem.

Resultados: $\mathrm{O}$ estilo de vida dos estudantes na sua globalidade é muito bom, apresentando valores mais baixos na atividade física/associativismo, alteração do padrão nutricional, alteração do sono e baixa capacidade para gerir o stresse, trabalho/tipo de personalidade e introspeção o que lhes propicia uma visão menos otimista e positiva.

Conclusáo: $\mathrm{O}$ plano de intervenção que contempla o apoio, educação, proteção e prevenção, deve ser adequado às necessidades individuais e integrado nos curricula.

Palavras-chave: perfil de saúde; estilo de vida; estudantes de enfermagem

*MSc., Adjunct Professor, Portuguese Red Cross Nursing School of Oliveira de Azeméis, 3720-126, Oliveira de Azeméis, Portugal [fernandaprincipe@esenfcrpoa.eu].Contribution to the article: literature search, data collection and analysis, discussion of results, and article revision. Address for correspondence: Avenida Nossa Senhora das Flores 1985, Bemposta, 3720-126, Oliveira de Azeméis, Portugal.

**MSc., Adjunct Professor, Portuguese Red Cross Nursing School of Oliveira de Azeméis, 3720-126, Oliveira de Azeméis, Portugal [saxoenfermeira@gmail.com]. Contribution to 3720-126, Oliveira de Azemeis, Portugal [saxoenfermeira@gmail.com].
the article: statistical data analysis, discussion of results, article revision.

***:Ph.D., Adjunct Professor, Nursing School of Coimbra, 3046-851, Coimbra, Portugal [irmabrito@esenf.pt].Contribution to the article: discussion of results, article revision. ****:Ph.D., Coordinating Professor, Nursing School of Porto, CINESIS (Center for Health Technology and Services Research), 4200-072, Porto, Portugal [mrs@esenf.pt].Contribution to the article: discussion of results, article revision.

\section{Resumen}

Marco contextual: La definición del perfil de salud de los estudiantes de enfermería es fundamental para desarrollar comunidades académicas salutogénicas.

Objetivo: Analizar el perfil de salud de los estudiantes, considerando la definición de estrategias de intervención a través del modelo PRECEDE- PROCEED.

Metodología: Estudio cuantitativo. La recogida de datos fue efectuada con la versión portuguesa de los cuestionarios: Estilo de Vida Fantástico, Escala de Autoimagen de Stunkard, Escala de Autoestima de Rosenberg y Cuestionario del Bienestar Psicológico. En este estudio, participaron 224 estudiantes de los cursos de licenciatura y pos licenciatura de especialización en enfermería. Resultados: El estilo de vida de los estudiantes, en su totalidad, es muy bueno, pues presentan valores más bajos en la actividad física/asociativismo, alteración del patrón nutricional, alteración del sueño y baja capacidad para gestionar el estrés, trabajo/tipo de personalidad e introspección, lo que les propicia una visión menos optimista y positiva.

Conclusión: El plan de intervención que contempla el apoyo, la educación, la protección y la prevención debe adecuarse a las necesidades individuales e integrarse en los currículos.

Palabras clave: perfil de salud; estilo de vida; estudiantes de enfermería 


\section{Introduction}

Health promotion is a process aimed at empowering people toward increased self-control and better health. This process requires an approach centered on individual behaviors and includes multiple social and environmental interventions, which is not the focus of attention in most higher education institutions (HEIs) in the health area.

The transition to higher education is marked by a developmental transition, a "period of transition from adolescence to adulthood" (Santos, 2012 , p. 4). The way in which students experience this transition has a significant impact on their academic and behavioral performance and determines the need for specific interventions, based on a number of new and no less complex challenges such as changes in family dynamics, which are often motivated by students leaving home; the adaptation to an education system with different rules; the management of greater autonomy; and the anxiety caused by multiple adaptations. (Pimentel, Mata, \& Anes, 2013, p. 186)

In this sense, HEI play a key role as agents for the promotion of students' health.

Health promoting HEIs transform the health and sustainability of current and future societies and contribute to the well-being of people, the environment, and the planet (Okanagan $\mathrm{Na}$ tion Elder, 2015). In this way, they promote institutional success, by creating a positive culture of health, well-being, equity, and social justice, and improve the health of those who live, learn, work, and redefine themselves in academic settings (Okanagan Nation Elder, 2015). Thus, the process of transformation of HEIs into health-promoting settings will require a set of well-planned educational, political, legislative, or organizational interventions that support healthy lifestyles and conditions for individuals, groups, or communities and that contribute to a greater health literacy, thus reducing risk behaviors and improving the physical and social environments.

According to Alcântara da Silva et al. (2015), the major risks to higher education students' health are associated with the consumption of psychoactive substances (tobacco, alcohol and other drugs), nutritional practices and attitudes, physical activity and recreation, and changes resulting from emotional management and stress. "Academic parties often involve risk behaviors such as the excessive consumption of alcohol and illicit drugs, along with sexual risk practices, which may harm the health of those young people in attendance" (Homem, Brito, Torres, Rodrigues, \& Mendes, 2014, p. 148).

The involvement of HEIs in health promotion projects can have many benefits, namely the improved quality of life of those involved, enhanced scientific-pedagogical projects, an impact on local, regional and national health status, and an enhanced public image and wide recognition.

The epidemiological diagnosis of an HEI allows identifying behavioral and environmental factors that contribute to the development of health problems in the populations. Based on this assumption, an epidemiological diagnostic study was conducted in a nursing school based on the PRECEDE-PROCEED model (Green $\&$ Kreuter, 2005). This study contributed to analyzing students' health profile with the purpose of designing intervention strategies based on the PRECEDE-PROCEED model "to promote the health of individuals and of the target population of future interventions" (Ferreira, Pereira, \& Ferreira, 2014, p. 101). Health profiling allows characterizing nursing students based on the factors that directly or indirectly influence their health status.

The epidemiological diagnosis in this study corresponds to one of the phases of the PRECEDE-PROCEED model (Green \& Kreuter, 2005), which was used in a more comprehensive study of participatory health research aimed at transforming a specific HEI into a healthy setting.

\section{Background}

The main challenge of a health-promoting HEI is to integrate health promotion into academic policies and practices. This can be achieved through 1) the development of health policies and planning of sustainable strategies, in which a solution can be community mobilization; 2) the creation of healthy work and leisure environments, and availability of social support and health care services; 3) empowerment for personal and social development; 4) increased academic interest in health-promoting activities; and 5) partnerships with the community from a health perspective.

In this process, it is important to consider the epidemiological diagnosis that represents a moment of evaluation in the PRECEDE-PROCEED (Predisposing, Reinforcing, and Enabling Constructs in Educational/ecological Diagnosis and Evaluation - Policy, Regulatory, and Organizational Constructs in Educational and Environmental Development) model 
developed by Green and Kreuter (2005). This model is used in several countries and encompasses a wide range of factors that influence preventive behaviors. This study will focus on the PRECEDE phase because it is associated with the collection and analysis of epidemiological data in order to identify the most important behaviors and problems for the diagnosis of a situation, which will serve as basis for the implementation phase (PROCEED). "The epidemiological diagnosis for health promotion focuses on modifiable risk factors" (Brito, 2014, p. 52), namely the evaluation of nursing students' health profile and lifestyles through the study of their self-image, self-esteem, and perceived psychological well-being.

Lifestyles are characterized by recognizable behavioral patterns that can have a significant impact on the health and well-being of individuals or communities.

According to Vaz Serra (1986), self-esteem is an important component of self-concept, and it is associated with individuals' perception of their own abilities and performance.

"Perceived body image, which is an important component of personal identity, is a multidimensional construct that represents how individuals perceive their own body" (Ferreira, Menezes et al., 2014, p. 291).

"Psychological well-being is a multidimensional construct that reflects characteristics related to a positive or optimal psychological functioning" (Machado \& Bandeira, 2012, p. 593).

\section{Research questions}

What is nursing students' health profile?

What are the factors influencing nursing students' health profile during their transition to higher education in nursing?

\section{Methodology}

The study was conducted at the Portuguese Red Cross Nursing School of Oliveira de Azeméis (ESEnfCVPOA) as a longitudinal, quantitative study with a descriptive and correlational approach. Its target population was composed of undergraduate and postgraduate nursing students during the 2012-2013 academic year, in a total of 254 participants. Of the total number of students (254), 224 students answered the questionnaire $(88.2 \%)$, which was considered to be a good response rate.

In order to examine nursing students' health profile, the Portuguese versions of the following questionnaires were applied: the Fantastic Lifestyle Assessment Questionnaire (Silva, Brito, \& Amado, 2014), the Stunkard Figure Rating Scale (Scagliusi et al., 2006), the Rosenberg Self-Esteem Scale (Santos \& Maia, 2003), and the short version of the Psychological General Well-Being Index (PGWB-S; Grossi et al., 2006).

The Fantastic Lifestyle assessment questionnaire (Silva et al., 2014) is a self-report instrument that allows identifying healthy lifestyles and behaviors. The instrument consists of 30 closed-ended items divided into 10 domains (FANTASTICO: F - Family and Friends, A - Physical activity/Affiliation, $\mathrm{N}$ - Nutrition, T - Tobacco, A - Alcohol and Other drugs, S - Sleep/Stress, T - Work/Type of personality, I - Insight, C - Health and sexual behaviors, and $\mathrm{O}$ - Other behaviors). Each item has three answer options $(0,1$, or 2$)$. The sum of all points gives a score from 0 to 120 . Behaviors are divided into five levels: 0 to 46 (needs improvement), 47 to 72 (fair), 73 to 84 (good), 85 to 102 (very good), and 103 to 120 (excellent). The Stunkard Figure Rating Scale (Scagliusi et al., 2006) consists of nine pictures that represent several body figures, ranging from very thin (score of 1) to very obese (score of 9). Participants are asked to choose one picture that they think represent their current body figure, one that represents a healthy body figure, and one that represents what they think is the ideal body figure. This scale produces five variables: 1) a number corresponding to the current body figure; 2) a number corresponding to the healthy body figure; 3) a number corresponding to the ideal body figure; 4) a score for the discrepancy between the healthy and current body figures (the current body figure number minus the healthy body figure number); and 5) a score for the discrepancy between the ideal and current body figures (the current body figure number minus the ideal body figure number). Participants who score closer to zero have a more real perception and are less dissatisfied.

The Rosenberg Self-Esteem Scale (Santos \& Maia, 2003) is rated on a 4-point Likert-type scale between 0 (strongly disagree) and 3 (strongly agree). The total score ranges from 0 to 40 , and higher scores indicate higher self-esteem.

The short version of the PGWB-S (Grossi et al., 2006) consists of six dimensions: Anxiety; Vitality; Depressed mood; Self-control; Positive well-being; and General health. Each dimension is rated on a 6-point Likert scale (0-5). The total score ranges from 0 to 30; the higher the score, the greater is the participant's psychological well-being.

Data were analyzed through descriptive, correlational, and inferential statistics, which are more 
appropriate to the type of data, using IBM SPSS Statistics V22.0. Pearson's correlation coefficient showed the inter-item correlation of the Fantastic Lifestyle Assessment questionnaire, as well as the association between each dimension of the instruments used and the attribute variables. The t-test was used to compare the means of the instruments' dimensions with the gender variable.

Participation was voluntary and anonymity was ensured. Participants were informed that could they withdraw from the study, which did not happen. The study was approved by the president of the ESEnfCVPOA Board of Directors.

\section{Results}

In this sample, the students' mean age was approximately 25 years $(S D=6.08)$, ranging from 17 to 46 years. The majority of students were women (83\%). Most of the 224 participating students attended the undergraduate degree in nursing $(75 \%)$. The remaining students at- tended postgraduate specialization degrees: medical-surgical nursing, 9.4\%; rehabilitation nursing, $10.3 \%$; and mental health and psychiatry nursing, $5.4 \%$. The study participants had a mean of three enrollments in higher education $(S D=1.74)$, ranging from one to nine enrollments.

Participants' total mean score regarding their lifestyle was $91.75 \pm 12.94$ points, which corresponds to the category of 85-102 points - Very good. None of the participants scored lower than 46 points, 13 participants $(5.8 \%)$ scored 47-72 points - Fair, 47 participants (21\%) scored 73-84 points - Good, 128 participants (57.1\%) Scored 85-102 points - Very good, and 36 participants (16.1\%) scored 103-120 points - Excellent. The analysis of the Fantastic Lifestyle Assessment questionnaire domains showed higher mean scores in the Family and friends and Other behaviors domains, such as personal protection and road safety, and lower mean scores in the domains of Physical activity/ Affiliation, Nutrition, Sleep/Stress, Work/Type of personality, and Insight (Table 1).

Table 1

Descriptive statistics of participants' lifestyles

\begin{tabular}{lcccc}
\hline Domains & Minimum & Maximum & Mean & $\begin{array}{c}\text { Standard } \\
\text { deviation }\end{array}$ \\
\hline Family and friends & 2 & 8 & 7.47 & 1.21 \\
Physical activity/Affiliation & 0 & 12 & 6.68 & 3.03 \\
Nutrition & 0 & 12 & 7.69 & 2.17 \\
Tobacco & 0 & 8 & 6.22 & 2.57 \\
Alcohol and Other drugs & 8 & 24 & 21.88 & 2.60 \\
Sleep/Stress & 0 & 12 & 8.52 & 2.73 \\
Work/Type of personality & 2 & 12 & 7.61 & 2.27 \\
Insight & 0 & 12 & 8.66 & 2.60 \\
Health and Sexuality behaviors & 2 & 12 & 9.36 & 2.14 \\
Other behaviors & 4 & 8 & 7.48 & 0.96 \\
Global & 54 & 120 & 91.75 & 12.94 \\
\hline
\end{tabular}

Pearson's correlation coefficient showed that the different domains of the Fantastic Lifestyle Assessment questionnaire were interrelated (Table 2). A positive and significant correlation was found between the domains with the lowest mean scores, Physical activity/Affiliation, Nutrition, Sleep/Stress, Work/Type of personality, and Insight. 
Table 2

Correlation matrix of the Fantastic Lifestyle Assessment questionnaire domains

\begin{tabular}{|c|c|c|c|c|c|c|c|c|c|c|}
\hline & $\mathrm{F}$ & A & $\mathrm{N}$ & $\mathrm{T}$ & A & $S$ & $\mathrm{~T}$ & I & $\mathrm{C}$ & $\mathrm{O}$ \\
\hline $\mathrm{F}$ & 1 & & & & & & & & & \\
\hline A & $\begin{array}{c}0.206^{* *} \\
0.002\end{array}$ & 1 & & & & & & & & \\
\hline $\mathrm{N}$ & $\begin{array}{l}0.053 \\
0.427\end{array}$ & $\begin{array}{l}0.112 \\
0.095\end{array}$ & 1 & & & & & & & \\
\hline $\mathrm{T}$ & $\begin{array}{l}0.165^{*} \\
0.013\end{array}$ & $\begin{array}{c}-0.022 \\
0.745\end{array}$ & $\begin{array}{c}0.180^{* *} \\
0.007\end{array}$ & 1 & & & & & & \\
\hline A & $\begin{array}{l}0.066 \\
0.325\end{array}$ & $\begin{array}{l}0.031 \\
0.649\end{array}$ & $\begin{array}{l}0.070 \\
0.297\end{array}$ & $\begin{array}{c}0.364^{* *} \\
0.000\end{array}$ & 1 & & & & & \\
\hline$S$ & $\begin{array}{c}0.246^{*} \\
0.000\end{array}$ & $\begin{array}{c}0.261^{* *} \\
0.000\end{array}$ & $\begin{array}{c}0.258^{* *} \\
0.000\end{array}$ & $\begin{array}{l}0.050 \\
0.458\end{array}$ & $\begin{array}{l}0.077 \\
0.253\end{array}$ & 1 & & & & \\
\hline $\mathrm{T}$ & $\begin{array}{c}0.245^{* *} \\
0.000\end{array}$ & $\begin{array}{c}0.324^{* *} \\
0.000\end{array}$ & $\begin{array}{c}0.212^{* *} \\
0.001\end{array}$ & $\begin{array}{l}0.089 \\
0.185\end{array}$ & $\begin{array}{l}0.172^{*} \\
0.010\end{array}$ & $\begin{array}{c}0.567^{* *} \\
0.000\end{array}$ & 1 & & & \\
\hline I & $\begin{array}{c}0.220^{* *} \\
0.001\end{array}$ & $\begin{array}{c}0.228^{* *} \\
0.001\end{array}$ & $\begin{array}{l}0.225^{* *} \\
0.001\end{array}$ & $\begin{array}{l}0.072 \\
0.284\end{array}$ & $\begin{array}{l}0.011 \\
0.865\end{array}$ & $\begin{array}{c}0.583^{* *} \\
0.000\end{array}$ & $\begin{array}{c}0.519^{* *} \\
0.000\end{array}$ & 1 & & \\
\hline C & $\begin{array}{l}0.167^{*} \\
0.012\end{array}$ & $\begin{array}{l}0.129 \\
0.054\end{array}$ & $\begin{array}{c}0.189^{* *} \\
0.005\end{array}$ & $\begin{array}{l}0.029 \\
0.661\end{array}$ & $\begin{array}{l}0.017 \\
0.803\end{array}$ & $\begin{array}{c}0.318^{* *} \\
0.000\end{array}$ & $\begin{array}{c}0.295^{* *} \\
0.000\end{array}$ & $\begin{array}{c}0.326^{* *} \\
0.000\end{array}$ & 1 & \\
\hline $\mathrm{O}$ & $\begin{array}{l}0.089 \\
0.185\end{array}$ & $\begin{array}{l}0.079 \\
0.241\end{array}$ & $\begin{array}{l}0.051 \\
0.444\end{array}$ & $\begin{array}{c}-0.040 \\
0.548\end{array}$ & $\begin{array}{l}0.149^{*} \\
0.026\end{array}$ & $\begin{array}{l}0.062 \\
0.357\end{array}$ & $\begin{array}{c}0.220^{* *} \\
0.001\end{array}$ & $\begin{array}{l}0.016 \\
0.816\end{array}$ & $\begin{array}{c}0.179^{* *} \\
0.007\end{array}$ & 1 \\
\hline
\end{tabular}

*Significant correlation at $p=0.05$. ${ }^{* *}$ Significant correlation at $p<0.001$

The gender distribution of the Fantastic Lifestyle Assessment questionnaire domains showed that women walked less than $30 \mathrm{~min}-$ utes per day than men $(t(222)=-2.94, p=$ $0.004)$, smoked more cigarettes per day than men $(t(221)=2.43, p=0.016)$, drank a significantly less amount of alcoholic beverages on one occasion than men $t(222)=4.19, p$ $<0.001$, were less able to manage day-to-day stress than men $t(222)=-3.43, p=0.001$, felt less confident and optimistic than men $t(222)=-2.90, p=0.004$, and finally, used seatbelts more often than men $t(222)=2.20$, $p=0.029$.
With regard to self-image, participants scored between -1 and 1 , which corresponds to a good self-image $(79 \%)$. However, $21 \%$ of participants were dissatisfied with their body image.

As regards self-esteem, participants had an overall high mean score of $34.20(S D=4.53)$, ranging from 19 to 40 .

The items of the Rosenberg Self-Esteem Scale were divided into two factors: factor 1 includes negative orientation items $(2,5,6,8$, and 9) and factor 2 includes positive orientation items (1, 3, 4, 7, and 10). Participants had balanced mean scores on both factors (Table 3).

Table 3

Descriptive statistics of participants' self-esteem

\begin{tabular}{lcccc}
\hline Self-esteem & Minimum & Maximum & Mean & $\begin{array}{c}\text { Standard } \\
\text { deviation }\end{array}$ \\
\hline Negative & 1.60 & 4.00 & 3.39 & 0.610 \\
Positive & 2.00 & 4.00 & 3.46 & 0.429 \\
\hline
\end{tabular}


Women had less self-esteem (33.80) than men (36.16), $t(222)=-3.81, p<0.001$.

With regard to psychological well-being, participants had a mean score of 15.07 (SD

$=2.24)$, varying between 11 and 22 points (Table 4).

Table 4

Descriptive statistics of participants' psychological well-being

\begin{tabular}{lcccc}
\hline Dimension & Minimum & Maximum & Mean & Standard deviation \\
\hline Anxiety & 0 & 5 & 2.66 & 1.215 \\
Vitality & 0 & 5 & 2.13 & 0.901 \\
Depressed mood & 0 & 4 & 1.88 & 0.992 \\
Self-control & 0 & 5 & 2.88 & 1.095 \\
Positive well-being & 1 & 5 & 3.07 & 1.024 \\
General health & 1 & 5 & 2.45 & 0.991 \\
\hline
\end{tabular}

Pearson's correlation coefficient was used to analyze the correlation between the different dimensions of psychological well-being and the attribute variables.

A negative and significant correlation was found between weight and general health $(r$ $=-0.199, p=0.034)$. Thus, excess weight is associated with poor health.

Age is negatively correlated with anxiety $(r=$ $-0.304, p=0.001)$ to the extent that perceived anxiety decreases with age. A negative correlation was found between age and vitality $(r=$ $-0.332, p<0.001)$, insofar as vitality decreases with age. Age was negatively and significantly correlated with depressed mood $(r=-0.289$, $p=0.002)$, so younger participants tend to feel more depressed. Both self-control $(r=$ $0.338, p<0.001)$ and positive well-being $(r=$ $0.273, p=0.003$ ) increase with age, thus suggesting that older participants are happier. In general, participants' psychological well-being decreases with age, $r=-0.213, p=0.024$.

\section{Discussion}

On average, study participants have a very good lifestyle, which is in line with the results found by Silva et al. (2014). In a study conducted by Alcântara da Silva et al. (2015), although students reported an excellent lifestyle, their lifestyle worsened after enrolling in a HEI. The admission into higher education "is a period of change marked by the conquering of more autonomy and respon- sibility.” (Tassini, Val, Candido, \& Bachur, 2017, p. 120). Thus, interventions should be planned to minimize the impact of the transition through health promotion upon students' first enrollment. The identification of the domains with a greater impact on students' lifestyles allows implementing interventions targeted at individual needs.

The domains of Physical Activity/Affiliation, Nutrition, Sleep/Stress, Work/Type of personality, and Insight had the lowest mean scores. The low mean scores in Physical activity/Affiliation can be explained by the fact that this is not a key area in the undergraduate nursing degree; hence, it is important to promote this type of extracurricular activities. The admission into an HEI is marked by changes in dietary habits, particularly when students are away from their family environment and are influenced by their peers with whom they now share new experiences. "These are potentially key moments of transition in the change of dietary habits, which may even mark trajectories of future practices and risk perceptions" (Alcântara da Silva et al., 2015, p. 81). Students "adopt practical and fast habits, such as a preference for industrialized products, low intake of fruits, vegetables and legumes, and omission of meals" (Tassini, et al., 2017, p. 121). According to Moorhead, Johnson, and Maas (2010), the following indicators should be taken into account when assessing students' eating habits: healthy nutritional practices (type of diet, frequency of meals); relationship among diet, exercise, and 
weight; strategies to change dietary habits. In the elaboration of the intervention plan, the definition of outcome indicators allows for a clearer definition of tangible goals.

The issues related to altered Sleep/Stress may arise from the fact that "anxiety and stress, as well as concentration difficulties, are the most common symptoms among the vast majority of students" (Alcântara da Silva et al., 2015, p. 48). Changes in sleep patterns and stress may be associated with students' admission into higher education and its associated new demands. However, it should be noted that social and personal factors have an impact on how students experience this transition. In the study developed by Tassini et al. (2017), students had difficulty in reconciling leisure, sleep, free time, and activities demanded by the university, and reported feeling tired and stressed with the daily routine, which is in line with the results of this study in what concerns the correlation between the domains of Physical Activity/Affiliation, Nutrition, Sleep/Stress, Work/Type of personality, and Insight. Thus, individuals who have better sleep quality and a greater stress management ability are happier and more optimistic and positive about life. As a result, sleep and stress disorders should be taken into account when designing an intervention plan based on the assessment of students' areas of vulnerability. The participants in this study had lower mean scores in the domains of Work/Type of personality than the participants in the study conducted by Silva and Brito (2014).

In comparison to male students, female students smoke more and consume less alcohol and other drugs; in addition, it is also evident that they are less able to manage stress, feel less confident and optimistic, and have a lower self-esteem. The greater consumption of alcohol found among men is consistent with the results obtained by Pimentel et al. (2013) and Rodriguez-Gázquez, Chaparro-Hernandez, and González-López (2016).

In general, students have an average psychological well-being. The lower scores are found in the dimension of Depressed mood, revealing feelings of discouragement among students. Depressed mood is defined as "Negative emotion: Feelings from sadness to melancholy with decreased concentration, loss of appetite and insomnia" (Conselho Internacional de Enfermeiros, 2016, p. 62). This negative emotion has a significant impact on students' academic performance, which may influence their quality of life. The academic path is marked by new demands, so it is essential to design and implement intervention strategies with a view to minimizing its impact on students' well-being and quality of life. "The important here is to support, educate, protect, and prevent any negative consequences on health caused by academic and socialization challenges" (Pimentel et al., 2013, p. 199). For this reason, the integration and monitoring of higher education students throughout this period are very important for their quality of life and academic success. Curricula should be properly aligned with students' individual needs to promote a healthy and sustainable development during their academic studies. The implementation of programs aimed at promoting students' health will contribute to a healthier population.

A limitation of this study may relate to the fact that students may have answered the questions based on what would be expected of them rather than on their true intent, which may have influenced the results.

\section{Conclusion}

Nursing students' health profile is characterized by low levels of Physical activity/Affiliation, changes in nutritional and sleep patterns, low stress management ability, as well as a Work/Type of personality and Insight that makes them less optimistic and positive about life. All these domains are interrelated to the extent that a change in one domain has a significant impact on the others. Thus, the design of intervention strategies should include all domains. The intervention plan will produce better results if students themselves are directly involved in its design and if the plan is integrated into the curricula.

Female students smoke more and drink less alcohol; however, they are less able to manage stress, feel less confident and optimistic, and have a lower self-esteem.

Students have an average psychological 
well-being. The lower scores were found in the domain of Depressed mood. Negative emotions have a significant impact on academic performance.

Future studies should focus on designing interventions capable of predicting the risk level of each student entering higher education, by defining vulnerability criteria in order to implement interventions targeted at individual needs.

\section{References}

Alcântara da Silva, P., Borrego, R., Ferreira, V., Lavado, E., Melo, R., Rowland, J., \& Truninger, M. (2015). Consumos e estilos de vida no ensino superior: $O$ caso dos estudantes da ULisboa/2012. Lisboa, Portugal: Observatório Permanente da Juventude.

Brito, I. (2014). Um modelo de planeamento da promoção da saúde: Modelo PRECEDE-PROCEED. In R. Pedroso, \& I. Brito (Eds.), Saúde dos estudantes do ensino superior de enfermagem: Estudo de contexto na Escola Superior de Enfermagem de Coimbra (Sér. Mon.12, pp.33-83). Coimbra, Portugal: Unidade de Investigação em Ciências da Saúde: Enfermagem/ Escola Superior de Enfermagem de Coimbra.

Conselho Internacional de Enfermeiros. (2016). Classificação internacional para a prática de enfermagem: CIPE versão 2015. Lisboa, Portugal: Lusodidacta.

Ferreira, A. A., Menezes, M. F., Tavares, E. L., Nunes, N., Souza, F., Albuquerque, N., ... Pinheiro, M. A. (2014). Estado nutricional e autopercepção da imagem corporal de idosas de uma Universidade Aberta da Terceira Idade. Revista Brasileira de Geriatria e Gerontolologia, 17(2), 289-301. Retrieved from http:// www.redalyc.org/articulo.oa?id=403838837007

Ferreira, F., Pereira, H., \& Ferreira, A. (2014). Autoestima e estilos de vida: Que relação nos estudantes de enfermagem? In IV Congresso de Investigaçao em Enfermagem Ibero-Americano e de Paises de Lingua Oficial Portuguesa, Coimbra, Portugal, 28 de julho de 2014 (p. 101)

Green, L. W., \& Kreuter, M. W. (2005). Health promotion planning: An educational and ecological approach. London, England: Mayfield Publishing Company.

Grossi, E., Groth, N., Mosconi, P., Cerutti, R., Pace, F., Compare, A., \& Apolone, G. (2006). Development and validation of the short version of the Psychological General Well-being Index (PGWB-S). Health and Quality of Life Outcomes, 4(88), 1-8.

\section{doi:10.1186/1477-7525-4-88}

Homem, F., Brito, I., Torres, A., Rodrigues, T., \& Mendes, F. (2014). Eles e elas: Comportamentos e consumos em contextos recreativos. In R. Pedroso, I. Brito (Eds.), Saúde dos estudantes do ensino superior de enfermagem: Estudo de contexto na Escola Superior de Enfermagem de Coimbra (Sér. Mon.12, pp.33-83). Coimbra, Portugal: Unidade de Investigação em Ciências da Saúde: Enfermagem/ Escola Superior de Enfermagem de Coimbra.

Machado, W., \& Bandeira, D. (2012). Bem-estar psicológico: Definição, avaliação, e principais correlatos. Estudos de Psicologia, 29(4), 587-595. Retrieved from http://www.scielo.br/pdf/estpsi/v29n4/ v29n4a13.pdf

Moorhead, S., Johnson, M., \& Maas, M. (2010). Classificação dos resultados de enfermagem (NOC). Porto Alegre, Brasil: Artmed.

Okanagan Nation Elder (2015). Okanagan Charter: An international charter for health promoting universities and colleges. International Conference on Health Promoting Universities and Colleges. VII International Congress. Retrieved from https:// open.library.ubc.ca/cIRcle/collections/53926/ items/1.0132754

Pimentel, M., Mata, M., \& Anes, E. (2013). Tabaco e álcool em estudantes: Mudanças decorrentes do ingresso no ensino superior. Psicologia, Saúde \& Doenças, 14(1), 185-204. Retrieved from http:// www.scielo.mec.pt/pdf/psd/v14n1/v14n1a12.pdf

Rodriguez-Gázquez, M., Chaparro-Hernandez, S., \& González-López, J. R. (2016). Lifestyles of nursing students from a Colombian public university. Investigación y Educación en Enfermería, 34(1), 94-103. doi:10.17533/udea.iee.v34n1a11

Santos, J. (2012). Estilo de vida relacionado à saúde de estudantes universitários: comparação entre ingressantes e concluintes. Programa de estudos pós-doutorais em Ciências da Saúde da Universidade Fernando Pessoa

Santos, P., \& Maia, J. (2003). Análise factorial confirmatória e validação preliminar de uma versão portuguesa da Escala de Auto-Estima de Rosenberg. Psicologia: Teoria, Investigação e Prática, 2, 253-268.

Silva, A., Brito, I., \& Amado, J. (2014). Tradução, adaptação e validação do questionário Fantastic Lifestyle Assessment em estudantes do ensino superior. Ciência \& Saúde Coletiva, 19(6), 1901-1909.

Scagliusi, F. B., Alvarenga, M., Polacow, V. O., Cordás, T. A., Queiroz, G. K. O., Coelho, D., Philippi, S. T., \& Lancha-Junior, A. H. (2006). Concurrent and discriminant validity of the Stunkard's figure rating scale adapted into Portuguese. Appetite, 
47(1),77-82.

Tassini, C., Val, G., Candido, S., \& Bachur, C. (2017). Assessment of the lifestyle of university students in the healthcare area using the Fantastic Questionnaire. International Journal of Cardiovascu- lar Sciences, 30(2),117-122. doi:10.5935/23594802.20170024

Vaz Serra, A. (1986). A importância do auto-conceito. Psiquiatria Clínica, 7(2), 57-66. 
